\title{
Digitally Born Records: Acquisition, Long-Term Preservation and Confirmation of Long-Term Legal Validity
}

\author{
ANDREI RYBAKOU, PH.D. \\ Director Belarusian Research Institute for Documentation and Archival Science (BelNIIDAD), + 375172867693 , \\ Minsk, Belarus \\ e-mail: rybakou@belniidad.by
}

\begin{abstract}
Digitally Born Records: Acquisition, Long-Term Preservation and Confirmation of Long-Term Legal Validity
\end{abstract}

\begin{abstract}
The article is devoted to the identification and possible solution of problems associated with transfer of digitally born (electronic) records to archives, ensuring their long-term preservation, integrity and legal significance for further use. The author notes that at present conceptual approaches to the construction of a system for the acquisition of electronic records by state archives, organization of their stock-taking, storage and use have been developed. These archival processes are supposed to be performed in four stages. For the storage of electronic records, it is planned to create a centralized repository of electronic documents based on the cloud service. However, a number of issues still require a solution. Some of them are in the legal sphere, others are of a technological nature. The traditional problem for archivists is the limited financial resources necessary to implement the plan.
\end{abstract}

Key words: electronic record, acquisition, stock-taking, usage of archival records, cloudy service, archival repository, long-term preservation, legal validity

I documenti nativi digitali: acquisizione, conservazione a lungo termine e mantenimento a lungo termine della validità legale

\section{SINTESI}

L'articolo è dedicato all'identificazione e all'eventuale soluzione dei problemi associati al trasferimento di archivi (elettronici) nativi digitali, garantendo la loro conservazione a lungo termine, integrità e significato giuridico per ulteriore utilizzo. L'autore osserva che attualmente sono stati sviluppati da parte degli archivi statali approcci concettuali per la costruzione di un sistema per l'acquisizione di documenti elettronici, l'organizzazione della loro conservazione ed utilizzo. Questi processi di archiviazione dovrebbero essere eseguiti in quattro fasi. Per la memorizzazione dei record elettronici, è previsto un deposito centralizzato di documenti elettronici basati sul servizio cloud. Tuttavia, una serie di problemi aspettano tuttora una soluzione. Alcuni gravitano nella sfera legale, altri sono di natura tecnologica. Il problema tradizionale per gli archivisti è dato dalle limite risorse finanziarie necessarie per portare avanti il piano.

Parole chiave: documento elettronico, acquisizione, stoccaggio, uso dei documenti archivistici, servizi su cloud, deposito d'archivio, conservazione a lungo termine, validità legale

Izvirno digitalno arhivsko gradivo: pridobivanje, dolgoročna hramba in dolgoročna pravna veljavnost

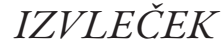

Članek je posvečen prepoznavanju in možnm rešitvam težav, povezanih s prenosom izvirnega digitalnega (elektronskega) arhivskega gradiva v arhive, ki zagotavljajo njihovo dolgoročno hrambo, celovitost in pravni pomen za nadaljnjo uporabo. Avtor ugotavlja, da so bili v tem času razviti idejni pristopi za izgradnjo sistema za pridobivanje elektronskih zapisov v državni arhiv, organizacijo njihovega zbiranja, skladiščenja in uporabe. Ti arhivski procesi naj bi se izvajali v štirih fazah. Za hrambo elektronskih zapisov se načrtuje vzpostavitev centraliziranega repozitorija za elektronsko arhivsko gradivo, ki bo temeljil na storitvi oblaka. Toda številna vprašanja še vedno ostajajo nerešena. Nekatera so pravne, druga tehnološke narave. Kot običajno, pa predstavljajo za arhiviste največjo težavo omejena finančna sredstva, potrebna za izvajanje načrta. 
Andrei RYBAKOU: Digitally Born Records: Acquisition, Long-Term Preservation and Confirmation of Long-Term Legal Validity, 183-191

Ključne besede: elektronski zapis, pridobivanje, prevzemanje, uporaba arhivskega gradiva, storitev oblaka, arhivsko skladišče, dolgoročna hramba, pravna veljavnost

Электронныя дакументы: камплектаванне, забеспячэнне доўгатэрміновай захаванасці і юрыдычнай значнасці

\section{РЭЗЮМЭ}

Артыкул прысвечаны выяўленню і магчымаму вырашэнню праблем, звязаных з арганізацыяй прыёму электронных дакументаў у архівы, забеспячэннем іх доўгатэрминовай захаванасці, цэласнасці і юрыдычнай значнасці для наступнага выкарыстання. Аўтар адзначае, што ў цяперашні час распрацаваны канцэптуальныя падыходы да пабудовы сістэмы камплектавання дзяржаўных архіваў электроннымі дакументамі, арганізацыі ix уміку, захоўвання і выкарыстання. Гэтыя архіўныя працэсы мяркуецца выконваць у чатыры этапы. Амя захоўвання электронных дакументаў плануецца стварэнне цэнтралізаванага сховішча электронных Аакументаў на аснове хмарнага сэрвісу. ААнак шэраг пытанняў па-ранейшаму патрабуе вырашэння. Адны 3 іх знаходзяцца ў юрыдычнай плоскасці, іншыя носяць тэхнацагічны характар. Традыцыйнай праблемай дмя архівістаў з' яўляюцца абмежаваныя фінансавыя рэсурсы, неабходныя дмя рэалізацыі задуманага.

Кмючавыя словы: электронны дакумент, камплектаванне, улік і выкарыстанне архіўных дакументаў, хмарны сервіс, архівасховішча, забеспячэнне доуггатэрміновай захаванасці і юрыдычнай значнасці

\section{Introduction}

Digitally born records (hereinafter - electronic records) have been used for a long time in the current activities of various organizations. The use of electronic records, electronic records circulation, is stimulated by the state and the creation of an electronic government has been announced as one of the state priorities in many countries. In Belarus, for example, all state bodies and state organizations, as well as business associations, in relation to which the state can determine the decisions they make, were instructed to acquire (develope, modernize) the departmental electronic records circulation systems that should provide the opportunity for interaction with the Interdepartmental Electronic Records Circula-

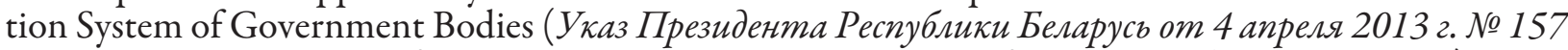
«О внесении изменений и дополнений в некоторые Указы Президента Республики Беларусь»). Mоst recently, the Government adopted the State Programme "Development of the Digital Economy and the Information Society for the years 2016-2020" (Постановление Совета Министров Республки Беларусь от 23 марта 2016 г. № 235 «Об утверждении Государственной программы развития иифровой экономики и информачионного общества на 2016-2020 годы»)).

Modern information technologies are actively implemented in the state archives, covering an increasing number of areas of their activities. Now active work is being done to create the Open Access System to the Documents of the National Archival Fond (Система открытого доступа к документам Начионального архивного фонда Республик Беларусь). Within the framework of this project, at the first stage the State Catalogue of Fonds kept by all state archives was put into the Internet (Фондовыци каталог государственныхх архивов Республики Беларусь), at the second stage archival inventories are being put into the Internet, and in the final stage digital images (scanned copies) of all documents kept in the state archives of the country will be introduced in the Internet network (Носевич, Сигневич, 2015; Носевич, Сигневич, 2017). The project will allow users to get access to all archival documents via the Internet without leaving the house.

However, for archivists at the present time the greatest interest is not the informatization of archives in itself (means the digitization of paper documents to ensure their easy and prompt search and use, including via the Internet). For archivists, it is now much more important to determine the solution of professional issues of accepting for storage in the archive documents initially created in the form of digital (electronic) records with no paper equivalents, as well as ensuring their long-term preservation, confirmation of long-term validity, authenticity and integrity throughout the storage period. Without solving these issues, it is impossible to implement electronic records circulation systems including documents of permanent and long-term storage. These documents create the basis of the National Archival Fond, they are the main objects of archivist's professional interest. 
Andrei RYBAKOU: Digitally Born Records: Acquisition, Long-Term Preservation and Confirmation of Long-Term Legal Validity, 183-191

It should be noticed that databases and databanks, other information resources (Internet sites, etc.) due to the specifics of their creation and existence are not considered in this article.

\section{Legislative regulation of creation, use and storage of electronic records in organizations}

The issues of creation, use and operative storage of electronic records are regulated at the legislative level to a sufficient extent. In Belarus a set of legislative acts regulating the relevant processes has been developed. The main ones are:

Law of the Republic of Belarus On Electronic Record and Electronic Digital Signature (3акон Республики Беларусь Об электронном документе и электронной иифровой подписи, 2009) ${ }^{\circledR 1}$;

Law of the Republic of Belarus On Archival Work and Records Managment in the Republic of Belarus (Закон Республики Беларусь Об архивном деле и делопроизводстве в Республике Беларусь, 2011);

Instruction on Records Management in the State Bodies an Other Organizations (Инструкция nо делопроизводству в государственньх органах, иньх организачиях, 2016) (hereinafter the Instruction on Records Management);

Instruction on the Procedure of Appraisal and Transfer for Permanent Storage of Records in Electronic Form and Information Resources (Инструкция о порядке проведения экспертиизь ценности и передачи на постоянное хранение документов в электронном виде и информачионных ресурсов, 2012);

Instruction on the Order of Organization of the Work with Records in electronic Form in Archives of State Bodies and Other Organizations (Инструкиия о порядке организаиии работы с документами в электронном виде в архивах государственньцх органов, иньх организачий, 2012).

The analysis of the requirements of the above mentioned regulatory legal acts was published earlier (Rybakou, 2015). However, it is worth noting some changes that have occurred in the last two years in the sphere of regulating the creation, circulation and storage of electronic records.

Firstly, in December 2015, the Instruction on Records Management was amended. According to the amendments, any documents allowed to be created in electronic form without paper equivalents, signed with a handwritten signature, only if the conditions for their storage in the archive of the organization are corresponding to the requirements defined by normative legal acts in the field of archives and records management (Постановление Министерства юостиии Республики Беларусь от 30 декабря 2015 2. № 225 «О внесении изменений и дополнений в постановление Министерства тостиции Республики Беларусь от 19 января 2009 г. № 4», 2015). Without paper analogues, documents of permanent storage, which are later must be transferred to the state archive, can also be created.

Legislatively, the possibility of creating electronic records without paper analogues was allowed earlier ${ }^{2}$, but in practice this norm was not applied to records of permanent and long-term storage. At the same time, the Instruction on Records Management still insists that if there are no relevant conditions in the archive of the organization, the creation of electronic records without signed paper originals is allowed only for those, that have a term of preservation no more than 10 years according to the list of such documents established in the Instruction (Инструкиия по делопроизводству в государственньхх органах, иньцх организащиях, 2016, par. 236). The existence of this restriction is due to the concern of archivists about the possibility to preserve valuable documents in the long term perspective and to ensure their legal validity during the storage period.

Secondly, the Instruction on Records Management and the Instruction on the Order of Organization of the Work with Records in Electronic Form in Archives of State Bodies and Other Organizations have been amended. According to the amendments the electronic record must be transferred to the archive of the organization before the electronic digital signature (hereinafter - EDS) loose its validity

1. A new version of the law is now being prepared.

2. The Law on Electronic Record and Electronic Digital Signature equated an electronic record signed by an electronic digital signature with a record on a paper medium. 
(Инструкиия по делопроизводству в государственных органах, иных организациях, 2016, раг. 205; Постановление Министерства ғостичии Республики Беларусь от 30 декабря 2015 г. № $226 \ll O$ внесении дополнений и изменений в постановление Министерства юстииии Республики Беларусв от 11 мал 2012 2. № 120,2015). These changes are due to the fact, that according to the legislation the EDS is the only means certifying the authenticity and integrity of the electronic document. So, if while transfering the electronic record to the archive, it turns out that the EDS is already invalid, there will be a question about the legal force and legal validity of such a record.

In addition, in 2015 a number of new state standards were adopted in the field of processing with electronic records:

Electronic records. The order of storage and use of public key certificates and revoke the certificates as the proof (CTБ 2402-2015);

Electronic records. Formats of electronic records for office work and storage of electronic records on archive (СТБ 2403-2015);

Electronic records. Protection, registration, storage and usage of electronic records in the archive (СТБ 2404-2015);

Electronic records. Creating a copy of an electronic record on the paper and procedure for certification (СТБ 2405-2015); 2015);

Electronic records. Policy for long-term preservation of electronic records in archives (СТБ 2406-

Electronic records. Creating electronic copies of documents on paper and procedure for certification (СТБ 2407-2015).

It should be noted that these standards do not contain any fundamentally new provisions and actually duplicate the requirements of the above mentioned legislative acts.

\section{Transfer of electronic records to the State Archives, their storage and pres- ervation}

As for the management of electronic records in the current activities of organizations, the main legal and technical problems are mostly solved. But with regard to the transfer of electronic records for archiving and ensuring their long-term preservation and long-term legal validity, problems still remain and only conceptual approaches have been developed.

According to the established requirements, initially the records, including the electronic ones, must be transferred for storage to the archive of the organization ${ }^{3}$. At the same time, organizations have the right to choose independently where to store electronic records: in an already created archive together with paper ones or in a specially created for these purposes electronic records archive. Legislation does not provide, but does not prohibit the use of services of a third-party organization for the storage of electronic records.

As for the transfer of electronic records for storage to state archives, at present time only two state archives accept electronic records for permanent storage. The Belarusian State Archive of Film, Photo and Phono Documents (i.e. audiovisual) preserves documents on its profile on all types of carriers, including electronic ones. The Archive of Electronic Documents of the Belarusian Research Center for Electronic Documentation (BelNICED) untill now takes for storage archival copies of electronic resources and other documents in electronic form that do not have an EDS (databases, Internet sites, etc.). At the same time, it should be taken into account that according to the Law on Electronic Record and Electronic Digital Signature only a record signed by an EDS is equated to a records on paper.

At present, the Archive of Electronic Documents of BelNICED is technologically unable to accept for storage and ensure the long-term preservation and long-term legal validity of electronic records signed by an EDS. It is assumed that after the modernization of the Archive of Electronic Documents of the

3. Law on Archival Work and Records Managment in the Republic of Belarus requires each organization to create an archive. 
BelNICED, the following system of electronic records transfer to state archives, their storage, preservation, stock-taking and usage will be built (Носевич, 2016).

At the first stage, the means of interaction between state archives and government bodies, other state organizations, which are obliged to transfer their documents for permanent storage to state archives (thereinafter fond-builders), will be created. For this purpose, it is planned to create a special Internet Portal, to which all state archives and fond-builders will be connected.

At the second stage, the fond-builder through the Portal will interact with the state archive in the implementation of such business processes as:

setting up a fond-builder into the list of organizations obliged to transfer their records for permanent storage to state archive;

stock-taking the records of permanent storage kept by the fond-builder before transferring them to state archive;

monitoring the availability of inventories for records of permanent storage, which must be transferred to state archive;

monitoring the transfer of electronic records for storage, etc.

The fond-builder will enter the necessary information on-line or send it in the form of an information package, then the Portal will provide these data to the state archive, which will import these data into its automated information system. The fond-builder will coordinate with the state archive the delivery inventory of documents to be transferred to the state storage (including both paper and electronic ones), then approve it and send the copy of the inventory to the state archive signed by the EDS.

At the third stage, the fond-builder will forward the information package describing all the electronic documents included in the delivery inventory with hash values, identifiers of the public key certificates of the EDS and the metadata necessary for stock-taking and subsequent storage of documents. For this purpose, it is planned to create a centralized repository of electronic documents. At this stage electronic records and electronic records files will be assigned archival names, and also the correspondence of these names to the archived ciphers (i.e. signatures) used in the archives will be established. The information package submitted by the fond-builder will be automatically imported into the centralized storage search system with the mandatory fixation of hash values and the impossibility of their subsequent modification.

At the fourth stage, the documents themselves will be uploaded with automatic verification of hash values and verification of the EDS. If the verification is successful, the documents arrive in the centralized repository. An information package with metadata of accepted electronic records will be sent to the state archive, then be imported into the automated information system of the archive and then integrated with data on paper records accepted by state archive and included in the same inventory. The fond-builder will receive a receipt or an act as a confirmation of the documents transfer. A receipt or an act will be signed in a remote with the EDS of the state archive.

The creation of a centralized electronic documents storage is supposed to be based on the cloud service. The system should provide on-line verification of hash values recorded at the time of the documents transfer, as well as the ability to convert data into new formats with obligatory recording the procedure and maintaining the original version.

The conceptual basis for the implementation of the project as a whole will be the International Standard ISO 14721:2012 "Space data and information transfer systems - Open archival informarion system (OAIS) - Reference model”.

\section{Problems}

1. The main difficulty is that the archives of state bodies and organizations are not yet equipped in the majority with technical and software tools that allow to check the authenticity of electronic records at the time of transfer, to ensure their proper storage and transfer for permanent storage to state archives. 
The state archives, which should accept electronic records for permanent storage, also do not have such means.

The State Programme "Development of the Digital Economy and the Information Society for the years 2016-2020" (Постановление Совета Министров Республики Беларусь от 23 марта 2016 г. № 235 «Обутверждении Государственной программььразвития цифровойэкономикииинформационного общества на 2016-2020 годъц», 2016) includes two tasks that will partially solve this problem: "Creating a trusted electronic repository for state bodies" and "Modernizing the information system for receiving electronic records of the National Archival Fond of the Republic of Belarus from state authorities and other organizations for permanent state storage, creating and commissioning a centralized repository to ensure their preservation and use". However, it is not yet known whether these events will be financed.

2. According to the law in force an EDS is the only legal means to confirm the authenticity and integrity of the electronic record (Закон Республики Беларусь Обэлектронномдокументе и электронной иифровой подписи, 2009). However, the validity period of an EDS is limited to a period of 1 to 5 years. This makes the archivists to think over how to confirm the integrity and authenticity (legal validity) of records in a longer term, including records of permanent storage.

The proposed model for transferring to the archive and storing electronic records assumes the use of a hash function for this purpose, which allows to calculate and fix the checksum (hash value). In subsequent storage, checking the hash value allows to determine whether intentional or accidental changes have been made to the record.

This technology has been used for a rather long time by the Archive of Electronic Documents of the BelNICED, but only with respect to large documents, mainly large information resources (databases, data banks, etc.). With regard to the verification of the authenticity and integrity of individual, single records (both on-line and archival storage), the use of this technology by legislation is not provided. To implement this idea, it is necessary to make appropriate changes to the Law on Electronic Record and Electronic Digital Signature.

3. Parallel solution also requires the issue of granting archivists the authority to monitor the integrity and authenticity of electronic records using a hash value, as well as the right to certify copies of electronic records issued to organizations and individuals both electronically and on paper.

According to the current legislation, a copy of an electronic record is a form of its external presentation on paper, certified by a notary or an authorized body that has a special permit (license) (Закон Республики Беларусь Об электронном документе и электронной иифровой подписи, 2009, art. 1, 20; Постановление Совета Министров Республики Беларусь от 20 июля 2010 г. № 1086 «Обутверждении Положения о порядке удостоверения формы внешнего представления әлектронного документа на бумажном носителе», 2010, par. 3). Archives are not among such bodies. In this regard, if the archive is required to submit a legally significant copy of the record on paper medium, it will have to contact the notary or an authorized body that has the appropriate license. If the archive is required to present a legally significant electronic record on an electronic medium, the issue of giving it legal significance is even more difficult to solve: the original EDS will be already invalid by that time, and the use of the EDS of the archive to certify such a record by law is not allowed. In fact, according to the current rules it occurs almost impossible to certify such an electronic record or its paper copy and to give it legal value.

The solution to this problem is also in the legislative sphere. The possible solution is in providing the archive with the right to certify copies of electronic records issued by it both on paper and electronic media. The corresponding right should be given to both state archives and archives of organizations.

4. It is necessary to develop regulatory requirements that clearly define the conditions for storing and preserving electronic records in the archives of organizations. Instruction on Records Management allows creating and storing documents in electronic form without originals on paper medium only if the conditions for storing and preserving electronic records created in the archive of the organization corresponds to the requirements established by regulatory legal acts (Инструкция по делопроизводству $в$ государственныхх органах, иных организациях, 2016, par. 236). But at present there are no such requirements in regulatory legal acts.

5. The creation of a centralized repository of electronic documents based on cloud services puts 
archivists before the need to solve problems related to the organization of secure storage of documents, their protection from external threats. The problems of storing and preserving documents in the cloud, migrating them to other formats are well known (Körmendy, 2015).

It should be noted that the System of Acquisition of Electronic Documents to State Archives, which is currently being developed, involves the possibility of search documents stored in a centralized repository by using the means of the Open Access System to the Documents of the National Archival Fond. This greatly increases the risk of information loss. In this regard, the system have to provide the possibility to create a backup copy of all stored information in case of failure or complete destruction of the cloud service (Hoce Bu, 2016). The solution of this task is costly from a financial point of view. In addition, archivists will have to decide whether the backup copy will be stored on fault-tolerant removable media or in a physically separate Data Center.

\section{Conclusion}

Last years in connection with the active implementation of an electronic record and electronic records circulation systems in the activities of various government bodies and other organizations, issues related to the organization of acquisition of electronic records by archives, ensuring their long-term preservation, integrity and long term legal validity became very actual. Without solving these issues, it is impossible to ensure a full transition to electronic records circulation, since documents of permanent and long-term storage are outside the scope of its application, but exactly these documents are the main object of archivists' interest.

In order to solve these tasks, measures are being taken to improve legislation in the sphere of the creation, circulation and storage of electronic records. Conceptual approaches to the organization of the system for the acquisition of electronic records by state archives, organization of their stock-taking, storage and use have been developed. These archival processes are supposed to be performed in four stages. For the storage of electronic records it is planned to create a centralized repository of electronic documents based on the cloud service.

Despite significant progress, a number of issues still need to be solved. Some of them are in the legal plane and require improvement of the legislative framework. These are the issues of legislatively fixing the possibility of using a hash value to confirm the integrity and authenticity of an electronic record in the archive after the expiration of the EDS, authorizing archivists to certify official copies of electronic records created on paper and electronic media, etc. Other issues are of a technological nature. These are the issues of ensuring the security of electronic documents in the conditions of using cloud technologies, the need to create a backup copy of all stored information in case of failure or complete destruction of the cloud service, etc. As usual, the implementation of the plan requires significant financial investments.

\section{References}

Указ Президента Республики Беларусь от 4 апреля 2013 г. № $157 \ll О$ внесении изменений и дополнений в некоторье Указы Президента Республики Беларусь». (2013). Available at http://www.pravo.by/upload/docs/ op/P31300157_1365195600.pdf(accessed on 11.04.2017).

Постановление Совета Министров Республики Беларусь от 23 марта 2016 г. № 235 «б утверждении Государственной программь развития чифровой экономики и информачионного общества на $2016-2020$ годъц». (2016). Available at http://www.government.by/upload/docs/file432d0daad31271d8.PDF (accessed on 11.04.2017).

Система открьтого доступа к документам Национального архивного фонда Республки Беларусь. Electronic resource. Available at http://archives-online.becloud.by/ (accessed on 11.04.2017).

Фондовьци каталог государственньх архивов Республики Беларусь. Electronic resource. Available at http://archives.gov.by/index.php?id=24 (accessed on 11.04.2017).

Носевич В., Сигневич А. (2015). Система открытого доступа к документам Национацьного архивного фонаа Республики Беларусь. In: Архівы і справаводства, № 1, pp. 72-79.

Носевич В., Сигневич $\Lambda$. (2017). Система открытого доступа к документам Национацьного архивного фонда Республики Беларусь внедрена в эксплуатацию и активно заполняется информацией. In: Apxiвы $і$ сnрававодства, № 1, pр. 69-75. 
Andrei RYBAKOU: Digitally Born Records: Acquisition, Long-Term Preservation and Confirmation of Long-Term Legal Validity, 183-191

Закон Республики Беларусь Об электронном документе и электронной иифровой подписи. (2009). Available at http://pravo.levonevsky.org/bazaby/zakon/zakb0709.htm (accessed on 12.04.2017).

Закон Республик Беларусь Об архивном деле и делопроизводстве в Республке Беларусь. (2011). Available at http://www.pravo.by/main.aspx?guid=4061\&p0=2011\&p1=136 (accessed on 12.04.2017).

9. Инструкция по делопроизводству в государственньх органах, иньх организауиях (2016). Минск: БелНИИААА.

Инструкция о порядке проведения экспертизь ценности и передачи на постоянное хранение документов в электронном виде и информационных ресурсов. (2012). Национальный реестр правовых актов Республики Бемарусь, № 58 .

Инструкция о порядке организачии работы с документами в электронном виде в архивах государственньх органов, иных организаций. (2012). Национальный реестр правовых актов Респубцики Бекарусь, № 58.

Rybakou, A. (2015). Management, Appraisal and Preservation of Electronic Records: the Belarusian Experience. In: Atlanti: Review for modern archival theory and practice, vol. 25, № 1, pp 61-70.

Постановление Министерства юстииии Республики Беларусь от 30 декабря 2015 г. № 225 «О внесении изменений и дополнений d постановление Министерства юстииии Республики Беларусь от 19 января 2009 г. № 4». (2015). Available at http://www.pravo.by/document/ ?guid=12551\&p0=W21630557\&p1=1 (accessed on 12.04.2017).

Постановление Министерства юстичии Республики Беларусь от 30 декабря 2015 г. № $226 \ll O$ внесении дополнений и изменений в постановление Министерства юстиции Республики Беларусь от 11 мая 2012 г. № 120». Available at http://www.pravo.by/document/?guid=12551\&p0=W21630552\&p1=1 (accessed on 12.04.2017).

СТБ 2402-2015: Государственный стандарт Республки Беларусь. Аокументы электронные. Порядокхранения и использования сертификатов открытых ключей и отозванных сертификатов в качестве доказательства. (2015). Минск: Госстандарт.

СТБ 2403-2015: Государственньй стандарт Республики Беларусь. Аокументы электроннысе. Форматы электронных документов для офисной работы и хранения электронных документов в архиве. (2015). Минск: Госстандарт.

СТБ 2404-2015: Государственный стандарт Республки Беларусь. Аокументы электронные. Порядок зашиmы, учета, хранения и использования электронных документов в архиве. (2015). Минск: Госстандарт.

СТБ 2405-2015: Государственньй стандарт Республики Беларусь. Аокументы электроннье. Создание копии электронного документа на бумажном носителе и порядок ее удостоверения. (2015). Минск: Госстандарт.

СТБ 2406-2015: Государственный стандарт Республки Беларусь. Аокументы электроннье. Политика долговременного хранения электронных документов в архивах. (2015). Минск: Госстандарт.

СТБ 2407-2015: Государственный стандарт Республики Беларусь. Аокументы электронные. Создание электронной копии документа на бумажном носителе и порядок ее удостоверения. (2015). Минск: Госстандарт.

Носевич В. (2016). Как обеспечить архивное хранение электронных документов. In: Apхівы і справаводства, № 4, pp. 83-94.

Постановление Совета Министров Республики Беларусь от 20 июля 2010 г. № 1086 «Об утверждении Положения о порядке удостоверения формы внешнего представления электронного документа на бумажном носите^е». (2010). Available at http://expert.by/EC/monitorings/144085.txt (accessed on 12.04.2017).

Lajos Körmendy. (2015). Information Society, E-records and the New Archival Science. In: Atlanti: Review for modern archival theory and practice, vol. 25, № 1, pp. 141-152.

\section{SUMMARY}

The active implementation of an electronic record in the activities of government bodies and other organizations, poses an ever greater challenge to archivists regarding the organization of acquisition of electronic records by archives, ensuring their long-term preservation, integrity and long term legal validity for subsequent use. In order to solve these tasks, measures are being taken to improve legislation in the sphere of the creation, circulation and storage of electronic records. Conceptual approaches to the organization of the system for the acquisition of electronic records by state archives, organization of their stock-taking, storage and use have been developed. These archival processes are supposed to be performed in four stages. For the storage of electronic records it is planned to create a centralized repository of electronic documents based on the cloud service. Nevertheless, a number of issues 
Andrei RYBAKOU: Digitally Born Records: Acquisition, Long-Term Preservation and Confirmation of Long-Term Legal Validity, 183-191

still need to be solved. Some of them are in the legal plane. These are the issues of legislatively fixing the possibility of using a hash value to confirm the integrity and authenticity of an electronic record in the archive after the expiration of the EDS, authorizing archivists to certify official copies of electronic records created on paper and electronic media, etc. Other issues are of a technological nature. These are the issues of ensuring the security of electronic documents in the conditions of using cloud technologies, the need to create a backup copy of all stored information in case of failure or complete destruction of the cloud service, etc. The traditional problem for archivists is the limited financial resources necessary to implement the plan.

Typology: 1.02 Review Article

Submitting date: 12.04.2017

Acceptance date: 05.05.2017 